九州大学学術情報リポジトリ

Kyushu University Institutional Repository

\title{
重症虚血肢に対する下腿バイパス手術の中期成績
}

Okazaki, Jin

Department of Surgery and Science, Graduate School of Medical Sciences, Kyushu University

Guntani, Atsushi

Department of Surgery and Science, Graduate School of Medical Sciences, Kyushu University

Homma, Kenichi

Department of Surgery and Science, Graduate School of Medical Sciences, Kyushu University

Kyuargi, Ryoichi

Department of Surgery and Science, Graduate School of Medical Sciences, Kyushu University 他

https://doi.org/10.15017/19680

出版情報 : 福岡醫學雜誌. 102 (2)，pp.31-39，2011-02-25. Fukuoka Medical Association バージョン：

権利関係: 


\title{
Original Article
}

\section{Mid-Term Clinical Outcome of Critical Limb Ischemia after Infrapopliteal Bypass Surgery}

\author{
Jin Okazaki, Atsushi Guntani, Kenichi Homma, Ryoichi Kyuragi, Eisuke Kawakubo, \\ Takuya Matsumoto, Ken Shirabe, Syunichi Tsujitani and Yoshihiko Maehara \\ Department of Surgery and Science, Graduate School of Medical Sciences, Kyushu University
}

\begin{abstract}
Objective : Critical limb ischemia caused by peripheral arterial occlusive disease of the infrapopliteal segment is best managed by bypass surgery with an autogenous vein conduit. Yet there remains confusing heterogeneity in the strategy, utilization, techniques, and outcomes in current practice. We reviewed our 7-year experience of infrapopliteal bypass surgery to analyze early and mid-term clinical outcomes.

Methods : From May 2003 through May 2010, 63 bypasses to the infrapopliteal artery were performed in 59 patients. This comprised $32.4 \%$ of the 194 infrainguinal arterial reconstructions performed during that period.

Results : Of the 63 bypasses, 57 were performed with an autologous vein and 6 with a composite graft. For the autologous vein bypasses, a single-segment great saphenous vein (GSV) was used in 39 bypasses, which included 23 reversed, 5 in situ, and 11 non-reversed free grafts. "Spliced" vein grafts, constructed by splicing the GSV or lesser saphenous veins (LSV) together, were utilized in 18 bypasses. No deaths occurred within 30 days of surgery. Two patients (3.5\%) died while hospitalized. Five grafts failed within 30days of surgery due to thrombosis or bleeding. The primary graft patency, secondary graft patency, amputation-free survival (AFS) and overall survival were 73.7\%, 82.4\%, 84.7\%, 88.1\%, respectively at 1 year and $65.4 \%, 76.3 \%, 71.0 \%, 74.6 \%$ at 3 years.

When patients were divided into groups based on the presence of end-stage renal disease on hemodialysis (HD), the 3-year secondary patency, AFS, and overall survival were 82.5\%, 49.2, 49.2\% in the HD group and $74.1 \%, 84.2 \%, 88.8 \%$ in the non-HD group. The overall survival in the HD group was significantly worse compared with the non-HD group.

Conclusion : Infrapopliteal arterial bypass is a safe, durable and highly effective procedure in patients with CLI, with excellent mid-term patency and amputation-free survival. Renal insufficiency may be associated with a poorer limb salvage rate and long-term survival.
\end{abstract}

Key words : Critical limb ischemia, Bypass surgery, Vein graft, Peripheral arterial occlusive disease

\section{Introduction}

Bypass surgery with an autogenous vein conduit has long been a gold standard and an established procedure to treat critical limb ischemia with excellent versatility, durability, and hemodynamic benefits. However, perioperative

Correspondence should be addressed to :

J. OKAZAKI

Department of Surgery and Science, Graduate School of Medical Sciences, Kyushu University, 3-1-1 Maidashi, Higashi-ku,

Fukuoka-shi, Fukuoka 812-8582, Japan

TEL : + 81-92-642-5466 FAX : + 81-92-642-5482

E-mail : jokazaki@surg2.med.kyushu-u.ac.jp morbidity after bypass surgery may be substantial, and graft failure still remains a major problem that has not been substantially reduced over the half century of technical improvements.

Peripheral arterial occlusive diseases in the infrapopliteal segment need special considerations, and there remains confusing heterogeneity in the strategies, utilization, techniques, and outcomes in current practice, and some patients are treated with primary amputation or endovascular treatments (EVT), which may be associated with poorer long-term outcomes. 
We herein present our 7-year experience and the mid-term clinical outcomes of infrapopliteal bypass surgery for CLI, and review the technical aspects and problems associated with this procedure.

\section{Materials and Methods}

The charts of 108 patients who underwent 128 infrainguinal bypass surgeries between May 2003 and May 2010 were retrospectively reviewed. The 128 infrainguinal bypasses included 35 above-knee femoropopliteal bypasses (AKFP), 30 below-knee femoropopliteal bypasses (BKFP), and 63 bypasses in which a distal anastomosis was at the infrapopliteal vessels. The demographic data, indications for surgery, comorbid conditions, specific details of the surgical procedure, complications, and outcome were assessed.

The surgical procedures were performed as follows. During the preoperative planning stage, routine intraarterial digital subtraction angiography was performed to evaluate the anastomosis site and run off vessels. Plain roentgenography was also performed to assess extensive calcification. In terms of selecting the outflow vessel, the most proximal vessel that provided continuous runoff to the forefoot was the primary target. The posterior tibial and anterior tibial arteries are good candidates for distal anastomosis. When these vessels were extensively calcified, a pedal artery or plantar artery is the next choice. The peroneal artery is infrequently used as a distal anastomosis. The common femoral artery is usually selected as the inflow artery. Concomitant iliac lesions were treated by angioplasty or bypass surgery to optimize inflow.

When the veins were limited, every effort was made to originate the graft from a distal inflow site, even if the superficial femoral artery had some disease, as long as it is not believed to be hemodynamically significant. The primary choice of graft is the ipsilateral or contralateral single-segment great saphenous vein (GSV). When a single-segment GSV with good quality was not available, then segments of either the GSV or lesser saphenous veins harvested from both legs were "spliced" together to construct a vein graft of sufficient length. We have not had any experience using arm veins at the present time. The graft direction (reversed or non-reversed) was principally decided based on the surgeon's preference. When the diameter of the GSV at the distal end was small, non-reversed grafts were chosen. In situ grafts were chosen only when the proximal anastomosis was set at the common femoral artery (CFA) or proximal superficial femoral artery (SFA). Most surgeries were done under general anesthesia with tracheal intubation. When a reversed or non-reversed free graft was selected, saphenous vein grafts were harvested through open incisions. All of the tributaries were ligated with $4-0$ silk ties and divided. Harvested grafts were irrigated and pressure dilated with heparinized saline, then one side of the graft was marked with dye to avoid twisting. For a non-reversed graft, valvulotomy was performed after proximal anastomosis, using a LeMaitre $^{\circledR}$ self-expandable valvulotome. In most cases, grafts were tunneled subcutaneously. Great care was taken to avoid twisting or kinking. Distal anastomosis was performed in an end-to-side fashion, using 7-0 or 8-0 polypropylene sutures. Completion angiography was routinely performed to check the anastomosis and distal runoff. When an in situ vein graft was selected, the tributaries were identified by angiography or ultrasonography, and ligated through added open incisions.

Grafts were considered patent if a palpable pulse was present over the graft or its run-off vessel. Limb salvage was defined as preservation of the foot at least at the level of transmetatarsal amputation. Wound healing was defined as a complete coverage of an ulcer or granulation tissue at the amputation stump by a skin or skin graft. After discharge, patients were followed at regular intervals, usually every 1 to 3 months during the first year, every 6 months in the second 
year and thereafter.

Statistical analyses were performed with the aid of the JMP software package (SAS institute Cary, NC, USA). Survival rates were calculated with the Kaplan-Meier product-limit method. The Mantel-Cox log rank test was used to compare survival curves among different groups.

\section{Results}

From May 2003 through May 2010, 63 bypasses to the infrapopliteal artery were performed in 59 patients. This comprised 32.4\% of the 194 infrainguinal arterial reconstructions performed during that period. The patient characteristics are shown in Table 1. The mean patient age was 71.2 years, and $68.4 \%$ of the patients were male. A total of $59.6 \%$ of the patients had diabetes mellitus, 28\% were undergoing dialysis at the time of surgery, and $56.1 \%$ were current smokers or had a smoking history. All operations were performed for critical limb ischemia; 55 limbs had tissue loss (Fontaine class IV) and 8 had rest pain (Fontaine class III).

Of the 63 bypasses, 57 were performed with an autologous vein and 6 with a composite graft. In composite grafts, the proximal ePTFE segment and distal autologous vein segment were anastomosed together. For the autologous vein bypasses, a single-segment great saphenous vein was used in 39 bypasses, which included 23 reversed, 5 in situ, and 11 non-reversed free grafts. Because of the limited availability of good quality sing-

Table 1 Patient demographics. IHD ; ischemic heart disease, CVD ; cerebrovascular disease, HD ; hemodialysis

\begin{tabular}{lccc}
\hline \hline \multicolumn{1}{c}{ Fontaine } & CLI (III \& IV) & III & IV \\
\hline Patients/Limbs & $57 / 63$ & $8 / 8$ & $49 / 55$ \\
Mean age & 71.2 & 68.1 & 71.7 \\
Male gender & $39(68.4 \%)$ & $5(62.5 \%)$ & $34(69.3 \%)$ \\
Diabetes mellitus & $34(59.6 \%)$ & $3(37.5 \%)$ & $31(63.2 \%)$ \\
Hypertension & $45(78.9 \%)$ & $7(87.5 \%)$ & $38(77.5 \%)$ \\
IHD & $26(45.5 \%)$ & $4(50.0 \%)$ & $22(44.8 \%)$ \\
CVD & $18(31.5 \%)$ & $2(25.0 \%)$ & $16(32.6 \%)$ \\
Smoking history & $32(56.1 \%)$ & $4(50.0 \%)$ & $28(57.1 \%)$ \\
HD & $16(28.0 \%)$ & $2(25.0 \%)$ & $14(28.5 \%)$ \\
\hline
\end{tabular}

le-segment GSVs, spliced vein grafts were utilized in 18 bypasses.

To optimize proximal inflow, 11 additional procedures were performed in advance or simultaneously, which included 8 PTA and stenting (6 for iliac and 2 for superficial femoral arteries), 1 axillofemoral bypass, 1 iliofemoral bypass, and 1 femoropopliteal bypass (Table 2). The proximal anastomoses were set at the iliac (3), common femoral (34), superficial femoral (7), above-knee popliteal (6), and below-knee popliteal (13) arteries. The distal anastomosis sites included 26 posterior tibial, 18 anterior tibial, 8

Table 2 Graft conduits and additional inflow reconstructions. GSV ; greater saphenous vein, PTA ; percutaneus transluminal angioplasty

\begin{tabular}{lr} 
Limbs & $\mathrm{n}=63$ \\
\hline \hline Graft conduit & \\
\hline Composite & 57 \\
Vein & 23 \\
reversed GSV & 11 \\
non-reversed GSV & 5 \\
in situ GSV & 18 \\
spliced vein &
\end{tabular}

Proximal inflow reconstructions

$\begin{array}{lr}\text { Iliac PTA/Stent } & 6 \\ \text { SFA PTA/Stent } & 2 \\ \text { Axillo-Femoral bypass } & 1 \\ \text { Iliofemoral bypass } & 1 \\ \text { Femoropopliteal bypass } & 1 \\ \text { None } & 52\end{array}$

Table 3 Graft origin and outflow target arteries. CFA ; common femoral artery, SFA ; superficial femoral artery

\begin{tabular}{cr} 
Limbs & $\mathrm{n}=63$ \\
\hline \hline Graft Origin & \\
\hline Iliac & 3 \\
CFA & 34 \\
SFA & 7 \\
Popliteal & 19 \\
\hline
\end{tabular}

\begin{tabular}{lr} 
Distal target artery & \\
\hline Posterior tibial & 26 \\
Anterior tibial & 18 \\
Peroneal & 8 \\
Dorsal Pedal & 8 \\
Plantar & 3 \\
\hline
\end{tabular}


peroneal, 8 dorsalis pedis, and 3 plantar arteries (Table 3).

No deaths occurred within 30 days of surgery. Two patients (3.5\%) died while hospitalized, one at 45 days postoperatively due to pneumonia, and the other at 75 days postoperatively, due to repeated bleeding and infection of the femoral to anterior tibial artery bypass. Five of the 63 grafts (7. 9\%) failed within 30 days due to thrombosis or bleeding, and 4 of the patients underwent early reoperation. A femoral to peroneal bypass with a spliced GSV graft and a femoral to anterior tibial artery bypasses with a non-reversed free GSV graft failed due to acute thrombosis, but both patients underwent successful replacement of severely stenotic segments of the old graft using a newly harvested GSV graft. A below-knee popliteal to plantar artery bypass with reversed GSV graft developed an acute thrombosis 10 days postoperatively, but was abandoned. A femoral to anterior tibial artery bypass with an in situ GSV graft had a rupture and bleeding at the mid portion of the graft 12 days of surgery, and the patient underwent replacement of the ruptured segment by a short ePTFE prosthetic graft. A patient with a below-knee popliteal to plantar artery bypass with a non-reversed free GSV graft developed bleeding at the distal anastomosis, which was repaired with additional sutures.

During the follow-up period, the primary patency, secondary patency, amputation-free survival (AFS), and overall survival were $73.7 \%$, $82.4 \%, 84.7 \%, 88.1 \%$, respectively at 1 year, and $65.4 \%, 76.3 \%, 71.0 \%, 74.6 \%$ at 3 years (Fig. 1 and 2). When the patients were divided into groups based on the presence of diabetes mellitus (DM group and non-DM group), and end-stage renal disease on hemodialysis (HD group and non-HD group), the 3 -year secondary patency were $82.5 \%$ in the HD group and $74.1 \%$ in the non-HD group, and $87.1 \%$ in the DM group and $63.0 \%$ in the non-DM group, respectively. The differences in patency were not significant between the groups (data not

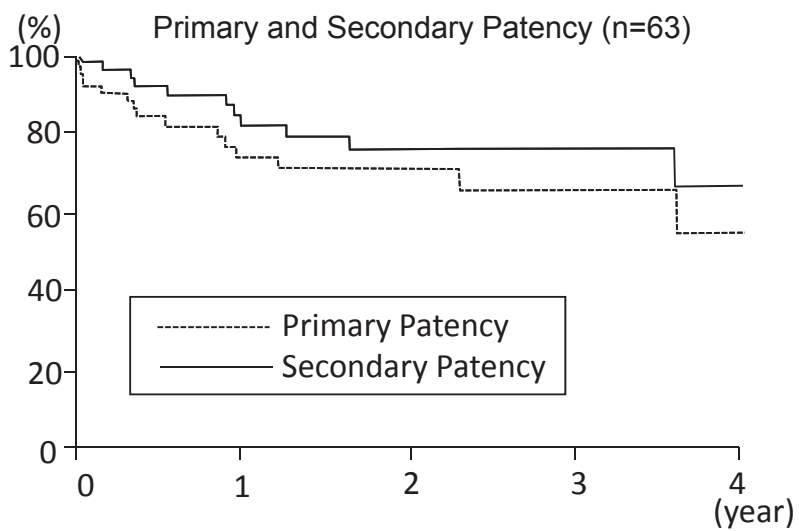

Fig. 1 Primary and secondary patency rates of all infrapopliteal bypass grafts. The standard error was $<10 \%$ at all time intervals.

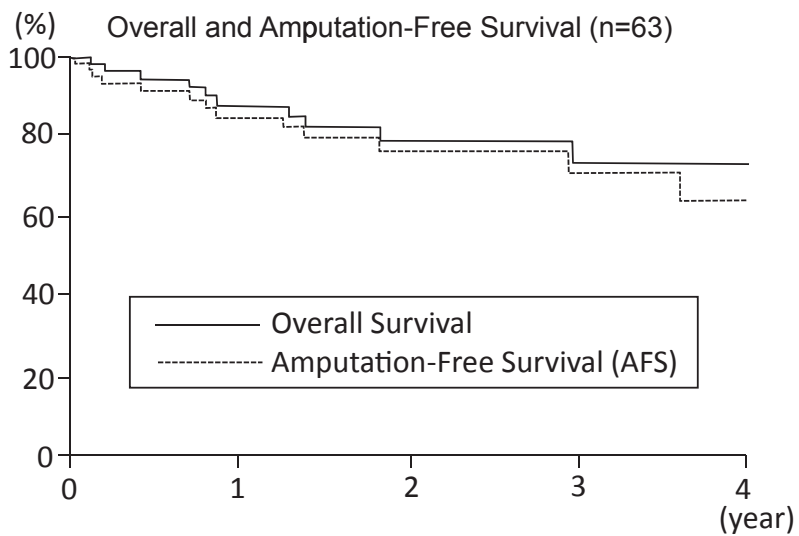

Fig. 2 Amputation-free survival and overall survival of all patients who underwent an infrapopliteal bypass. The standard error was $<10 \%$ at all time intervals.

shown). The amputation-free survival (AFS) and overall survival were 49.2 and $49.2 \%$ in the HD group and $84.2 \%$ and $88.8 \%$ in the non-HD group, $67.0 \%$,and $67.0 \%$ in the DM group and 76.7 $\%$ and $85.4 \%$ in the non-DM group, respectively. Regarding these differences, only the overall survival in the HD group was significantly worse than in the non-HD group (Fig. 3).

\section{Discussion}

In contrast to claudicants, patients with critical limb ischemia (CLI) suffer from multiple comorbidities and limited life expectancies. Even with appropriate management of the disease, up to $25 \%$ of patients die and 30\% lose their limb at 1 year. Successful surgical or endovascular interventions may decrease the need for amputation and 

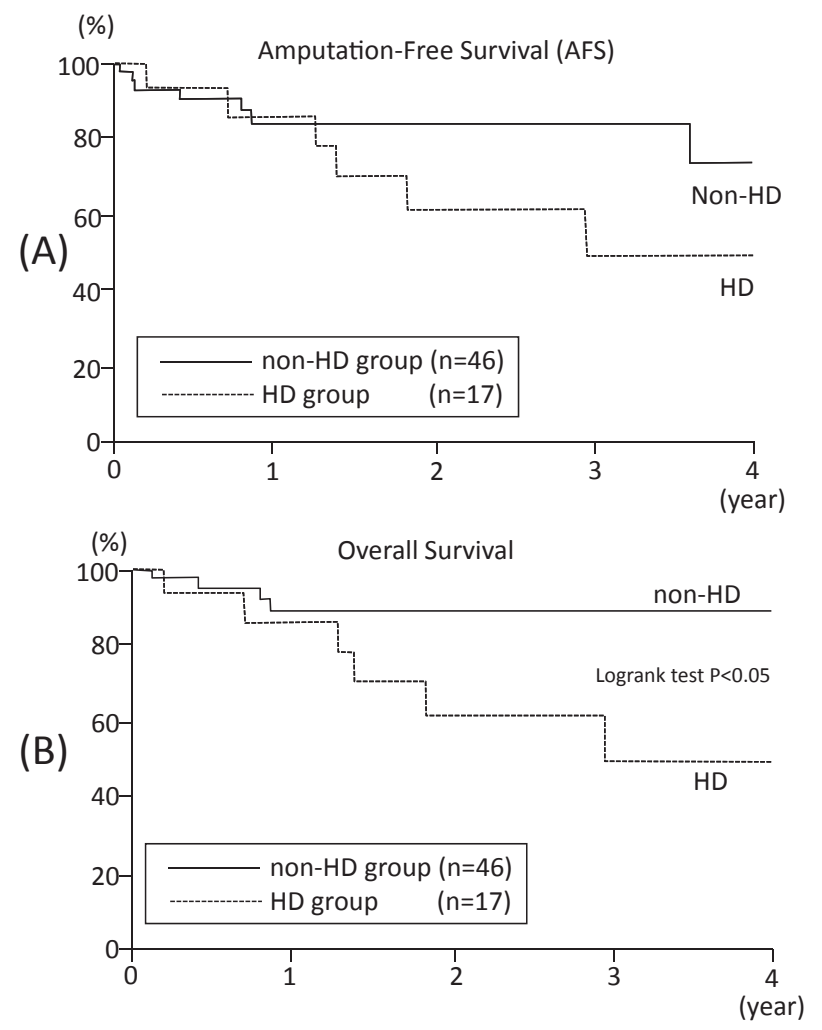

Fig. 3 Amputation-free survival (A) and overall survival (B) of patients who underwent infrapopliteal bypass with or without end-stage renal failure on hemodialysis. The overall survival was significantly ( $p$ $<0.05$ ) worse in the HD group.

contribute to a better survival rate.

Since the first description by Kunlin in $1949^{1)}$, autogenous vein bypass has remained the most versatile and durable revascularization for $\mathrm{PAD}$ below the inguinal ligament. Yet there remains significant variation in graft utilization, inflow optimization, outflow selection, and additional procedures. Optimization of the inflow artery is an important issue in preoperative planning. A diseased aortoiliac artery should be reconstructed by bypass surgery, endoarterectomy, or endovascular treatment(EVT), to ensure sufficient inflow at the proximal anastomosis. By recent advances in endovascular treatment, it may be possible to reconstruct the diseased superficial femoral artery by EVT and place the proximal anastomosis down to the popliteal artery, which is helpful when vein grafts are limited. These additional treatments have been shown to have no increased risk of adverse effects on the graft patency ${ }^{2)}$.

Selection of the outflow vessel had been another point of interest for distal bypass ${ }^{3)}$. The distal posterior tibial artery and anterior tibial artery communicate directly with the pedal arch. The peroneal artery, however, does not communicate directly with the forefoot, and therefore, its use as the outflow vessel has been the subject of some criticism because it can lead to suboptimal hemodynamic results, with a lower chance of healing necrotic wounds of the foot. Although there is no randomized data available, several reports have shown that the result of peroneal artery bypass were equivalent to those of posterior tibial or anterior tibial arteries ${ }^{4 / 5)}$.

Vein grafts may be excised and implanted in reversed or non-reversed, or placed in situ (not excised). In reversed grafts, the distal end of the excised graft, which may be smaller in diameter, is set at the proximal anastomosis. In situ grafts may be advantageous when optimizing artery-vein graft size mismatch at the anastomosis ${ }^{6}$. On the other hand, the valvulotome may cause graft injury, which can result in acute graft failure or bleeding ${ }^{7}$. A postoperative residual arteriovenous fistula can be ligated easily, but may cause acute graft thrombosis distal to the site of the fistula ${ }^{8)}$. A non-reversed free graft, in which the vein is completely mobilized, ensures a tension-free proximal anastomosis to the common femoral artery and eliminates the risk of an arteriovenous fistula $^{9)}$. The excised graft may be tunneled subcutaneously, anatomically (in Hunter's canal), or extra-anatomically. Subcutaneously placed grafts facilitate easier graft surveillance and simplify surgical revisions when needed. On the other hand, the grafts placed in a deeper location may have a reduced chance of developing a wound complication. Although each technical variation may have specific advantages and disadvantages, there are no data suggesting that the graft direction or location influences its patency ${ }^{10)}$.

The graft quality, however, does influence 
patency. Graft quality is assessed by the diameter, length, and whether it is a single-segment GSV or alternative "spliced" graft. In general, a single-segment GSV vs. a spliced GSV or alternative (lesser saphenous/arm) vein, grafts shorter than $40 \mathrm{~cm}$, and grafts with a diameter larger than $3.5 \mathrm{~mm}$ had significantly better primary and secondary patency ${ }^{11}$. In the absence of a suitable autologous vein conduit, a prosthetic graft is a reasonable alternative. However, prosthetic bypass grafts have only limited patency, especially for infrageniculate reconstruction. Adding a vein cuff in the distal anastomosis, or introduction of pre-cuffed prosthetic grafts have been shown to contribute some improvements in graft patency ${ }^{12)}$. Recently, heparin-bonded Dacron or ePTFE prosthetic grafts have shown acceptable early and mid-term patency and limb salvage rates ${ }^{13)}$, however, these results are still inferior to vein bypasses, even those using alternate veins.

In addition to these technical updates, vein graft bypass is already an established procedure to treat infrapopliteal lesions, with an excellent technical success, patency, and limb salvage rate, as long as there are good quality saphenous veins. Our data, although limited in the number of patients, shows good mid-term patency and amputation-free survival rate, which is comparable to existing large-scale data ${ }^{14}$.

Recently, endovascular treatment (EVT) has been shown to have acceptable initial success and early outcomes for femoral revascularization, and now is expanding its indication into the infrapopliteal segment, without reliable evidence. In 2002, the transatlantic inter-society consensus (TASC) II classification updated their recommended treatment of PAD in femoral-popliteal segments, in which the indication for endovascular treatment (EVT) has been widely expanded. However, the TASC II did not include their recommendations for the disease in infrapopliteal segments, because there have been no reliable data which have compared bypass and EVT.
The use of Bypass versus Angioplasty for Severe Ischemia of the Leg (BASIL) Trial, the only randomized trial to date to compare a revascularization strategy of bypass surgery-first with balloon angioplasty-first revascularization for advanced limb ischemia due to infrainguinal PAD, recently reported its long-term outcomes ${ }^{15)}$. It has shown that bypass surgery and balloon angioplasty lead to similar amputation-free survival (AFS) and overall survival (OS) at 2 years from randomization. However, for those patients who survived for more than 2 years after intervention, initial randomization to surgery was associated with a significant increase of AFS and OS. In addition, bypass surgery after failed EVT was associated with a poor outcome compared to primary bypass.

The BASIL trial also did not specifically analyze infrapopliteal arterial reconstructions. Although several single-center studies and a meta-analysis of infrapopliteal EVT for CLI have previously shown "acceptable" technical success rates, patency, and limb salvage rates in patients with limited longevity ${ }^{16) 17}$, there are still no reliable data showing any advantage of EVT over bypass surgery in terms of patency, durability, limb salvage, and short or long-term survival ${ }^{18)}$.

Patients with CLI have multiple comorbidities which may reduce their life expectancies ${ }^{19)}$. The impact of diabetes and renal failure need special consideration. Although data from large single-center series and randomized trials have demonstrated that diabetes does not affect graft patency, it is associated with a poor limb salvage rate and long-term survival ${ }^{20)}$. Patient survival and limb salvage after lower extremity bypass were also negatively affected by renal failure $\mathrm{e}^{21)}$. On the contrary, vein graft patency does not seem to be linked to renal disease. The distressing problem of the need for amputation despite a patent bypass graft may reflect poor wound healing and sepsis control due to their comorbid conditions $^{22)}$. Our data also suggest poorer life expectancies for patients with end-stage renal 
disease.

\section{Conclusion}

Infrapopliteal arterial bypass is a safe, durable and highly effective procedure in patients with CLI, with excellent mid-term patency and amputation-free survival. Patients with end-stage renal disease may have a poorer limb salvage rate and long-term survival.

\section{References}

1) Kunlin J. [The treatment of arterial obstruction by vein grafting.][Article in French] Arch Mal Coeur 42 : 371-374, 1949.

2) Ballotta E, Renon L, DeRossi A, Bardon B, Terranova $O$ and Da Giau G : Prospective rondamized study on reversed saphenous vein infrapopliteal bypass to treat limb-threatening ischemia : common femoral artery versus superficial femoral or popliteal and tibial arteries as inflow. J Vasc Surg 40 : 732-740, 2004.

3) Pompeselli FB, Jespen SJ, Gibbons GW, Cambell DR, Freeman DV, Miller A and LoGerfo FW : Efficacy of dorsal pedal bypass for limb salvage in diabetic patients : Short-term observations J Vasc Surg 11: 745-752, 1990.

4) Raftery KB, Belkin M, Mackey WC, and O'Donnell TF : Are peroneal artery bypass grafts hemodynamically inferior to other tibial artery bypass grafts? J Vasc Surg 19 : 964-969, 1994.

5) Bergamini TM, George SM, Massey HT, Henke PK, Klamer TW, Lambert GE, Banis JC, Miller FB, Garrison RN and Richardson JD : Pedal or peroneal bypass: Which is better when both are patent? J Vasc Surg 20 : 347-356, 1994.

6) Donaldson MC, Mannick JA and Whittemore $A D$ : Femoral-Distal bypass with in situ greater saphenous vein. Ann Surg 213 : 457-464, 1991.

7) Gannon MX, Goldman MD, Simms MH, Ruddock S, Ashton F and Slaney G : Perioperative complications of in-situ vein bypass. Ann Royal Coll Surg Eng 68 : 134-136, 1986.

8) Watelet J, Soury P, Menard JF, Plissonnier D, Pecillon C, Lestrat JP and Testart J : Femoropopliteal bypass : In situ or reversed vein grafts? Ten-year results of a randomized prospective study. Ann Vasc Surg 11: 510-519, 1997.

9) Beard JD, Wyatt M, Scott DJA, Baird RN and Horrocks M : The non-reversed vein femoro-distal bypass graft : a modification of the standard in situ technique. Eur J Vasc Surg 3 : 55-60, 1989

10) Schanzer A, Havelone N, Owens CD, Belkin M, Bandyk DF, Clowers AW, Moneta GL and Conte MS : Technical factors affecting autogenous vein graft failure : observations from a large multicenter trial. J Vasc Surg 46 : 1180-1190, 2007.

11) Conte MS : Technical factors in lower-extremity vein bypass surgery : How can we improve outcomes? Semin Vasc Surg 22 : 227-233, 2009.

12) Griffiths GD, Nagy J, Black D and Stonebridge PA : Randomized clinical trial of distal anastomotic interposition vein cuff in infrainguinal polytetrafluoroethylene bypass grafting. $\mathrm{Br} \mathrm{J}$ Surg 91 : 560-562, 2004.

13) Pulli R, Dorigo W, Castelli P, Dorrucci V, Ferilli F, Blasis GD, Monaca V, Vecchiati E and Pratesi $\mathrm{C}$ : Midterm results from a multicenter registry on the treatment of infrainguinal critical limb ischemia using a heparin-bonded ePTFE graft. J Vasc Surg 51 : 1167-1177, 2010.

14) Pompeselli FB, Kansal N, Hamdan AD, Belfield A, Sheahan M, Campbell DR, Skillman JJ and Logerfo FW : A decade of experience with dorsalis pedis artery bypass : Analysis of outcome in more than 1000 cases. J Vasc Surg $37: 307-315,2003$.

15) Bradbury AW, Adam DJ, Bell J, Forbes JF, Fowkers FG, Gillespie I, Ruckley CV and Raav GM : BASIL trial Participants. Bypass versus angioplasty in severe ischemia of the leg (BASIL) trial : an intention-to-treat analysis of amputation-free and overall survival in patients randomized to a bypass surgery-first or a balloon angioplasty-first revascularization strategy. J Vasc Surg 51 (5 Suppl) : 5S-17S, 2010.

16) Conrad MF, Kang JK, Cambria RP, Brewster DC, Watkins MT, Kwolek CJ and LaMuraglia GM : Infrapopliteal balloon angioplasty for the treatment of chronic occlusive disease. J Vasc Surg 50 : 799-805, 2009.

17) Romiti M, Albers M, Brochado-Neto FC, Durazzo AE, Pereira AB, and Luccia ND : Meta-analysis of infrapopliteal angioplasty for chronic critical limb ischemia. J Vasc Surg 47 : 975-981, 2008.

18) Beard JD. Which is the best revascularization for critical limb ischemia : Endovascular or open surgery? J Vasc Surg 48 : 11S-16S, 2008.

19) Shanzer A, Goodney PP, Li Y, Eslami M, Cronenwett J, Messina L and Conte MS : Validation of the PIII CLI risk score for the prediction of amputation-free survival in pa- 
tients undergoing infrainguinal autogenous vein bypass for critical limb ischemia. J Vasc Surg $50:$ 769-775, 2009.

20) Conte MS : Challenges of distal bypass surgery in patients with diabetes: Patient selection, techniques, and outcomes J Vasc Surg 52 : 96S-103S, 2010.

21) Owens CD, Ho KJ, Kim S, Schanzer A, Lin J, Matros E, Belkin M and Conte MS : Refinement of survival prediction in patients undergoing lower extremity bypass surgery : stratification by chronic kidney disease classification. J Vasc Surg 45 : 944-952, 2007.

22) Lantis JC 2nd, Conte MS, Belkin M, Whittemore $\mathrm{AD}$, Mannick JA and Donaldson MC : Infrainguinal bypass grafting in patients with end-stage renal disease : improving outcomes? J Vasc Surg 33 : 1171-1178, 2001.

(Received for publication January 18, 2011) 
(和文抄録)

\title{
重症虚血肢に対する下腿バイパス手術の中期成績
}

\author{
九州大学大学院 消化器 · 総合外科
}

岡 崎 仁, 郡谷篤史, 本間 健一, 久良木亮一, 川久保英介 松本拓也, 調憲, 辻谷俊一, 前原喜彦

慢性動脈閉塞症による重症下肢虚血は疼痛や潰瘍形成, 肢切断によりQOL を損ない, 生命予後 も不良な疾患である。特に下腿領域の病変に対しては自家静脈によるバイパス手術が有効な治療 法であるが，その適応，手術手技，成績および予後については各施設でばらつきが多く標準化され ているとは言い難い，我々は当施設で過去 7 年間に行われた下腿動脈領域へのバイパス手術につ いて，その術式および中期成績を分析した。 2003 年 1 月〜2010 年 5 月の間に重症虚血肢（CLI）に 対して行われた膝窩動脈より末梢への血行再建手術は 57 例 63 肢であった. 63 肢のバイパスグラ フトの内訳は, コンポジット 6 肢, reversed Great Saphenous vein (GSV) 23 肢, non-reversed GSV 11 肢，in situ GSV 5 肢，“Spliced” vein graft 18 肢であった，2例（3.5\%）に在院死を認めた． 5 肢のバイパスグラフトに早期閉塞を認め, 4 肢に対して再手術が行われた. グラフトの一次開存 率, 二次開存率, 非切断生存率, 生存率は術後 1 年で $73.7 \%, 82.4 \%, 84.7 \%, 88.1 \%$, 術後 3 年で 65.4\%,76.3\%,71.0\%,74.6\%であった。患者を透析群と非透析群に分けると 3 年後の二次開存率, 非切断生存率, 生存率は透析群で $82.5 \%, 49.2,49.2 \%$, 非透析群で $74.1 \%, 84.2 \%, 88.8 \%$ であり, 透析患者で有意に生存率が低かった。下腿領域の重症虚血肢に対する血行再建バイパス手術は, 良 好な生命予後・救肢率が期待でき, 再インターベンションの必要性も少なく重症虚血肢患者の QOL 向上に寄与する有効な治療法と考えられる. 透析患者においては開存・救肢率は良好なもの の生存率が低く，基礎疾患による生命予後を反映しているものと考えられた。 